\title{
Morphological rectal alterations following STARR performed for obstructed defecation syndrome
}

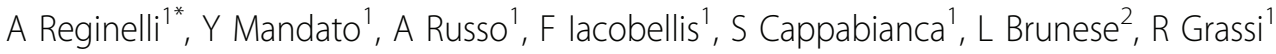 \\ From XXIII Annual Meeting of the Italian Society of Geriatric Surgery \\ Lecce, Italy. 2-4 December 2010
}

\begin{abstract}
Background
Anorectal functional disorders are common disease involving about a quarter of population. Most patients concerned are females complaining of one or more symptoms, with a negative impact on quality of life, and high social costs. Traditional surgical treatments are frequently unsatisfactory, indeed some surgeons opt for conservative therapy consisting in the pelvic floor rehabilitation. A new surgical technique, the STARR (stapled trans-anal rectal resection) seems to show encouraging results. STARR aims to improve obstructed defecation syndrome (ODS) symptoms by the correction of the associated rectal anatomical alterations, such as rectocele and/or rectal intussusception. Contraindications to STARR are represented by stenosis, perianal sepsis, malignancy, enteroceles, sigmoidocele.
\end{abstract}

\section{Patients and methods}

Thirty-five patients were investigated by dynamic defecography before and after STARR. Preoperative imaging findings were: rectocele, recto-rectal intussusceptions, internal mucosal rectal prolapse, full-thickness rectal prolapse, descending perineum and paradoxical puborectalis syndrome. Four and six months after surgery, defecographic follow-up was carried out.

\section{Results}

In only one case, the rectal intussusception was not corrected by surgical treatment; in two patients, partial reduction of rectocele was found. Two patients, in which the STARR corrected functional and anatomical defects, showed a iatrogenic rectal diverticulum anterior and posterior respectively. In thirty patients, an

\footnotetext{
* Correspondence: reginelli@tin.it

'Section of Radiology, Department "Magrassi-Lanzara," Second University of Naples, Naples, Italy

Full list of author information is available at the end of the article
}

"hourglass" stricture was found and the rectal ampulla was reduced in size and length.

\section{Conclusions}

The STARR represents an effective surgical treatment in patients with ODS symptoms. Dynamic defecography is a useful method to define patients who require surgical treatment and to investigate the causes of surgical failure or relapses.

\section{Author details}

'Section of Radiology, Department "Magrassi-Lanzara," Second University of Naples, Naples, Italy. 'Department of Radiology, Health Science, University of Molise, Campobasso, Italy.

Published: 24 August 2011

doi:10.1186/1471-2318-11-S1-A51

Cite this article as: Reginelli et al:: Morphological rectal alterations

following STARR performed for obstructed defecation syndrome. BMC Geriatrics 2011 11(Suppl 1):A51.

Submit your next manuscript to BioMed Central and take full advantage of:

- Convenient online submission

- Thorough peer review

- No space constraints or color figure charges

- Immediate publication on acceptance

- Inclusion in PubMed, CAS, Scopus and Google Scholar

- Research which is freely available for redistribution

Submit your manuscript at www.biomedcentral.com/submit
() Biomed Central

\section{() Biomed Central}

